\title{
Comparative evaluation of linseed varieties under environmental conditions of Tandojam Pakistan
}

\author{
Manthar Ali Sahito ${ }^{1}$, Abdul Haleem Sial ${ }^{1}$, Kamran Razzaque Kalwar ${ }^{1}$, \\ Babar Sultan Mengal ${ }^{1}$, and Fateh Muhammad Baloch ${ }^{2}$ and Ayaz Latif \\ Siyal $^{3 *}$ \\ 1. Department of Agronomy, Sindh Agriculture University, Tandojam, Pakistan \\ 2. Department of Social Sciences, Agriculture Research Institute Quetta (PARC), Pakistan \\ 3. Department of Plant Breeding and Genetics, Sindh Agriculture University Tandojam, Sindh, Pakistan \\ *Corresponding author's email:latifayazsiyal@gmail.com \\ Citation \\ Manthar Ali Sahito, Abdul Haleem Sial, Kamran RazzaqueKalwar, Babar SultanMengal, Fateh Muhammad \\ Baloch and Ayaz Latif Siyal. Comparative evaluation of linseed varieties under environmental conditions of \\ Tandojam Pakistan. Pure and Applied Biology. Vol. 11, Issue 1, pp92-99. \\ http://dx.doi.org/10.19045/bspab.2022.110010
}

\begin{tabular}{llll}
\hline \hline Received: 19/02/2021 & Revised: 23/04/2021 & Accepted: 27/04/2021 & Online First: 00/05/2021 \\
\hline \hline
\end{tabular}

\section{Abstract}

Variability and genetic diversity assessment is foremost activity to be embarked before any crop improvement programme. Divergence analysis is helpful in identifying suitable and diverse parents for realizing high heterotic effects with transgressive sergeants in later generations. Thus, a research study was design to study and the purpose of this study remained to evaluate the variation in seed germination, days taken to flowering and maturity, height of the plant, branches and capsules per plant, thousand grains weight, oil content percentage and seed yield kg per hector at Oilseeds Section, Agriculture Research Institute, Tandojam Pakistan. Six linseed varieties (including candidates and one commercial variety), viz., Pr-83, 84, 102, 17, 75 respectively and Ilsi-90 as check were evaluated for their growth, seed yield and oil yield performance. The field experiment was set up in Randomized Complete Block Design with three replications. The achieved results pointed out that except seed germination, all the growth and seed yield related traits as well as oil content differed significantly $(\mathrm{P}<0.05)$ in diverse linseed varieties. It was concluded that linseed candidate varieties $\operatorname{Pr}-75$ and $\operatorname{Pr}-17$ surpassed commercial linseed variety Ilsi-90 (check) in all the growth and seed yield works as well as in oil content, which is a most significant consequence of this experiment, and the varieties $\operatorname{Pr}-75$ and $\operatorname{Pr}-17$ could be promising for general cultivation in Sindh province.

Keywords: Environmental condition; Growth parameters; Linseed varieties; Seed germination;

Yield components

\section{Introduction}

During last dualistic decades, linseed (Linum usitatissimum L.), has been achievement more response, subsequently new perspectives for harvests as a good source of high value added raw material. Linseed is authoritative in the health and food marketplace as a functional food, its seeds and oil be a rich source of bio-active compounds [1]. Nowadays, by the enlargement of awareness of users towards the strong correlation between food and health, linseed started to be measured a very capable functional food, due to the presence, in its seeds, a highly nutrients and active compounds, high value proteins, dietary fibers and phenolic mixes [2]. Although, linseed can be capable to grow in unfavourable environmental conditions, which allows growth of the cultivated land 
area under various agro-ecological conditions [3]. Even, its chemical composition is strongly related with, and depending upon genetic characters, growth condition and management of crop, generally its seed content the lipid ranged

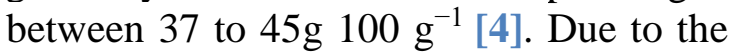
occurrence of mucilage fibres, it is also ingested for emetic properties. Linseed has also high linolenic acid content that made it an important ingredient for manufacture of paints, varnish, oil- cloth, printing ink, stains and polymer linoleum[5]. Because of the quick drying property that it imparts. Besides its oil, the linseed fibres are used by industries for producing high quality linen fabrics having high strength and durability, pulp and biofuel[6]. Ascribed to its both edible and non-edible uses, it has an increasing demand in agro based industries but its average productivity in India is very low as compared to other countries, due to lack of high yielding varieties, cultivation of crop in marginal lands coupled with disease, insect-pest problems, biotic and abiotic stresses.

Therefore, in this research study six varieties including a local check variety, of linseed were compared, in order to assess their agronomical and qualitative characteristics. Through an open field experiment, carried out in 2012-13 growing season in Oilseeds Section, Agriculture Research Institute, Tandojam, seed germination (\%) and oil content characteristics, yield and yield components, together with seed characterization were investigated.

\section{Materials and Methods}

\section{Plot establishment and management}

Initially, the land was well worked by executing deep ploughing to remove the hard pan of the experimental soil, and then precision land levelling was performed. After soaking dose, when the soil came in condition, the seedbed was prepared by executing crosswise cultivator ploughing and later soil was planked. The sowing was done with the help of single coulter hand drill. The recommended planting rate of $40 \mathrm{~kg} \mathrm{ha}^{-1}$; whereas row to row distance $60 \mathrm{~cm}$ and plant to plant distance $15 \mathrm{~cm}$ was maintained between rows.

\section{Field experiment}

A set of six linseed varieties including a local check as spring crops under field conditions, at Oilseeds Section, Agriculture Research Institute, Tandojam, (GPS coordinates $25^{\circ} 424032 \mathrm{~N}$ and $68^{\circ} 538830$ E) during 2012-13 Rabi season. The area net plot size of $3 \times 3.5 \mathrm{~m}\left(10.50 \mathrm{~m}^{2}\right)$ having five rows respectively. A field experiment was set up to compare the growth and yield performance of linseed under environmental conditions. Results regarding analysis of variances are indicated in (Table 1) while results regarding mean squires of seed germination, days taken to flowering and maturity, height of the plant, branches and capsules per plant, thousand grains weight, oil content percentage and seed yield $\mathrm{kg}$ per hector are shown in (Tables 2).

Table 1. Analysis of variance (mean square values) for different characters

\begin{tabular}{|c|c|c|c|c|c|c|c|c|c|c|}
\hline \multirow[b]{2}{*}{$\begin{array}{l}\text { Source of } \\
\text { Variance }\end{array}$} & \multirow[b]{2}{*}{ DF } & \multicolumn{9}{|c|}{ Mean Squire } \\
\hline & & $\begin{array}{c}\text { Seed } \\
\text { germination } \\
(\%)\end{array}$ & $\begin{array}{l}\text { Days to } \\
\text { flowering }\end{array}$ & $\begin{array}{l}\text { Days to } \\
\text { maturity }\end{array}$ & $\begin{array}{l}\text { Plant } \\
\text { height }\end{array}$ & $\begin{array}{c}\text { Branches } \\
\text { plant }^{-1}\end{array}$ & $\begin{array}{l}\text { Capsule } \\
\text { s plant }^{-1}\end{array}$ & $\begin{array}{l}1000 \text { gr } \\
\text { weight }\end{array}$ & $\begin{array}{c}\text { Oil } \\
\text { content } \\
(\%)\end{array}$ & $\begin{array}{l}\text { Seed yield } \\
\left(\mathrm{kg} \mathrm{ha}^{-1}\right.\end{array}$ \\
\hline Replication & 2 & 20.09 & 1.16 & 2.38 & 3.23 & 0.03 & 46.88 & 0.12 & 1.63 & 10677.5 \\
\hline Varieties & 11 & $14.22^{\mathrm{NS}}$ & $14.23 * *$ & $33.28 * *$ & $\begin{array}{c}19.83 * \\
*\end{array}$ & $0.44 * *$ & $231.3^{*}$ & $0.61 *$ & $16.35^{*}$ & $30500.6^{* *}$ \\
\hline Total & 35 & -- & -- & -- & -- & -- & -- & -- & -- & -- \\
\hline
\end{tabular}




\section{Plant materials}

The following varieties were evaluated for their growth and yield performance.

\section{Varieties}
V1. Pr-83
V2. Pr-84
V3. Pr-102
V4. Pr-17
V5. Pr-75
V6. Ilsi-90 (check)

\section{Fertilizer usage}

The N-P fertilizers were at the uniform rates of $100-60 \mathrm{~kg} \mathrm{ha}^{-1}$. The Nitrogen was applied in the form of urea, while phosphorus in the form of single super phosphate (SSP) All phosphorous and half of nitrogen was at the time of seedbed preparation, and remaining half $\mathrm{N}$ was applied at the time of first irrigation. The first irrigation was applied after one month of sowing; and subsequently the experimental crop was irrigated fortnightly. Weeding was done two times by inter culturing at the time of $1^{\text {st }}$ and $2^{\text {nd }}$ irrigation, respectively. The crop was harvested at physiological maturity by manual method using sickle. The whole harvested material was kept in bundles and shifted to threshing yard for drying purpose. The bundles were later threshed manually and weighed for recording seed yield.

\section{Observations recorded}

1. Seed germination $(\%)$

2. Days to flowering

3. Days to maturity

4. Plant of the height $(\mathrm{cm})$

5. branches plant ${ }^{-1}$

6. capsules plant ${ }^{-1}$

7. 1000 grains weight $(\mathrm{g})$
8. Oil content $(\%)$

9. Seed yield $\left(\mathrm{kg} \mathrm{ha}^{-1}\right)$

\section{Statistical analysis}

The outcomes for seed yield, oil content and agronomic parameters were administered by linear models ANOVA using statically analysing software Statistix 8.1. Differences between varieties and replications were deduced by Duncan's multiple range test $(p=0.05)$. Statistical results are on condition that in the Results and Discussion section.

\section{Results and discussion}

Analysis of variance

\section{Seed germination}

The seed germination of six linseed varieties was observed and the results are presented in (Table 2, Fig. 1). The analysis of variance (Table 1) indicated insignificant $(\mathrm{P}>0.05)$ difference between linseed varieties for seed germination percentage. The maximum seed germination 80.37 percent was observed in case of candidate linseed variety Pr-102 against 78.52 percent seed germination in variety Ilsi-90 (check). However, the lowest seed germination of 74.72 percent was observed in case of candidate variety $\mathrm{Pr}-75$. It was observed that all the varieties showed satisfactory performance for seed germination and germination is probably linked with the seed viability. While comparing the crop varieties for their agronomic performance, the factor that primarily contributes is supposed to be the crop stand, which is dependent on the viability of seed and subsequent seed germination percentage [7].

Table 2. Mean values of Seed germination (\%), days taken to flowering, days taken to maturity and plant height

\begin{tabular}{|c|c|c|c|c|}
\hline Varieties & Seed germination & Days to flowering & Days to maturity & Plant height \\
\hline Pr-83 & 75.02 & 70 & 101 & 96.24 \\
\hline Pr-84 & 77.8 & 69 & 100 & 93.87 \\
\hline Pr-102 & 80.37 & 72 & 104.33 & 97.59 \\
\hline Pr-17 & 76.4 & 72.67 & 105.33 & 93.2 \\
\hline Pr-75 & 74.72 & 74.33 & 108.33 & 100.29 \\
\hline Ilsi-90 & 78.52 & 69 & 100.33 & 96.24 \\
\hline
\end{tabular}




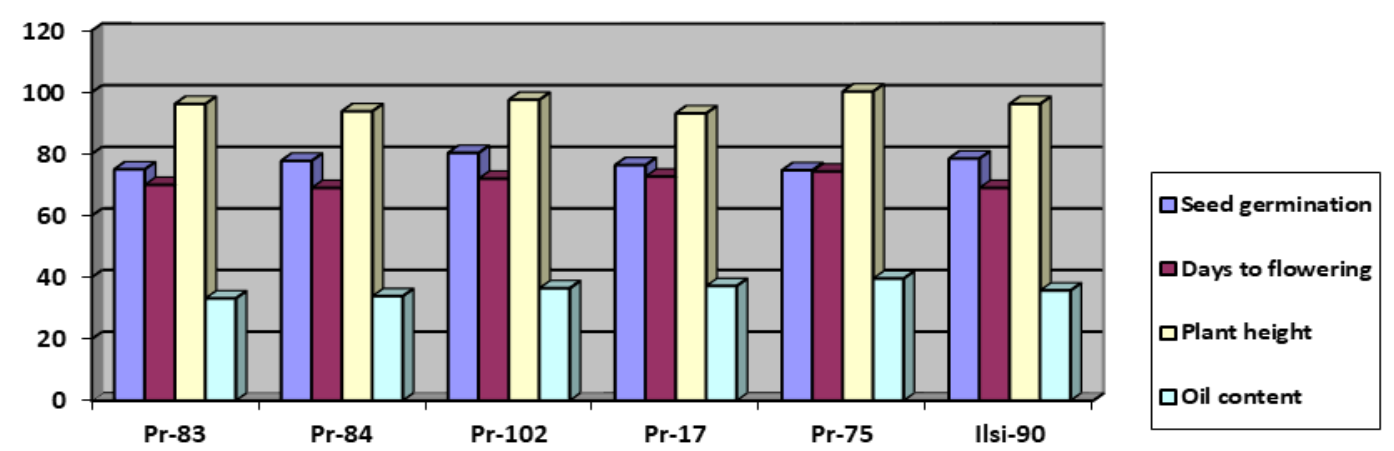

Figure 1. Comparative mean performance of seed germination, days to flowering, plant height and oil content $(\%)$

\section{Days taken to flowering}

The results in regards to days to flowering of six linseed varieties are given in (Table 2,Fig. 1) and its analysis of variance is shown as (Table 1). The analysis of variance described that the differences in the number of days to initiate flowering were significant $(\mathrm{P}<0.05)$ between linseed varieties. The flowering initiation took maximum number of days (74.33) in plots sown with linseed variety Pr-75. Relatively lesser number of days to initiate flowering (70.00), where observed in candidate variety Pr-83. Days taken to flowering is a plant characteristic that represents the physiology of plants to initiate flowering; and flowering initiation is mostly influenced by the genetic makeup of varieties, but the environmental and management conditions also influence the flowering initiation period.[8]Reported the importance of flowering days under water stress studies conducted on 20 exotic wheat genotypes earlier.

\section{Days taken to maturity}

The results pertaining to days taken to maturity of linseed varieties are presented in (Table 2, Fig. 2) whereas, its analysis of variance as (Table 1). The analysis of variance demonstrated that the differences in the number of days to maturity between linseed varieties were significant $(\mathrm{P}<0.05)$ statistically. The results showed that linseed variety Pr-75 took maximum number of days (108.33) to reach physiological maturity, followed by linseed varieties Pr17 and Pr-102.Generally, in plants, the days to maturity character is guided by the days to flowering, because in a similar plant species, the earliness or delay in flowering will lead to corresponding earliness or delay in physiological maturity of the crop. However, the environmental factors and the genetic behavior of certain genotypes for maturity cannot be overemphasized [9] find same results.

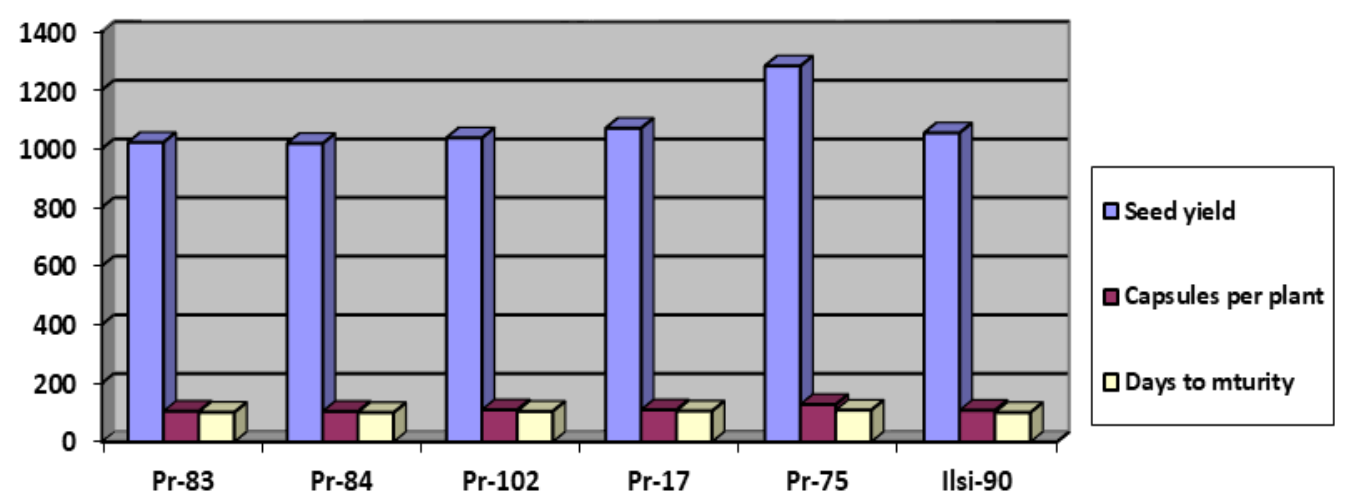

Figure 2. Comparative mean performance of seed yield, capsules per plant and days to maturity 


\section{Plant height}

Plant height is the shortest distance between the upper boundary of the main photosynthetic tissues excluding inflorescences on a plant and the ground level, expressed in this study in centimeters. The results pertaining to plant height of linseed varieties is given in (Table 2, Fig. 1) and its analysis of variance as (Table 1). The analysis of variance indicated that the differences in plant height of different linseed varieties were statistically significant $(\mathrm{P}<0.05)$. The plots sown with linseed variety $\operatorname{Pr}-75$ produced the plants of maximum height $(100.29 \mathrm{~cm})$ against 96.24 $\mathrm{cm}$ plant height in case of commercial variety Ilsi-90 (check). The study clearly indicates that Pr-75 is supposed to be the most promising line of all the candidate linseed varieties if plant height is considered in the selection criterion. [10] Who noted that withholding irrigation at booting and at anthesis stages caused significant reduction in wheat plant height. Plant height directly or indirectly contributes towards grain yield, yet it could serve as an important indicator of water stress tolerance via normal or retarded plant height.

\section{Branches plant ${ }^{-1}$}

Plants exhibit approximately form of branching, and principally in smaller plants the branching is steady and the crop yields are isprejudiced by the number of branches they produce. The results in regards to branches plant ${ }^{-1}$ of six linseed varieties are presented in (Table 3, Fig. 3) and its analysis of variance as (Table 1). The statistical analysis of variance described that the differences in branches plant $^{-1}$ of different linseed varieties were statistically significant $(\mathrm{P}<0.05)$. The crop comprised of linseed variety $\operatorname{Pr}-75$ possessed the maximum number of branches plant ${ }^{-1}$ (5.49), followed by varieties Pr-102 and Ilsi-90 (check) with 4.71 and 4.62 average branches plant ${ }^{-1}$, respectively. This greater number of branches in $\operatorname{Pr}-75$ was primarily associated with the plant height. Hence, in case of branching capacity, the Pr-75 and
Pr-102 could be considered as the most promising lines for using in future breeding programs on linseed. Found the visible effects of Environmental effect on branches number [11].

\section{Capsules plant ${ }^{-1}$}

Capsules contain the seeds in flowering plants like linseed, and it is generally said that more the capsules in a plant, greater the yield plant ${ }^{-1}$. The results pertaining to capsules plant ${ }^{-1}$ of six linseed varieties are assumed in (Table 3, Fig. 2) and its analysis of variance as (Table 1). The statistical analysis of variance proven significant $(\mathrm{P}<0.05)$ differences between various linseed varieties for the number of capsules plant ${ }^{-1}$. The number of capsules plant $^{-1}$ was highest (128.00) in candidate linseed variety Pr-75, followed by candidate varieties $\operatorname{Pr}-102$ and $\operatorname{Pr}-17$ possessing equal number of capsules (109.67) plant $^{-1}$, respectively. Hence, in case of capsules plant ${ }^{-1}$ is considered, the Pr-75, Pr-17 and Pr-102 could be the promising strains for future breeding programs on linseed crop. [12] reported at higher population density, showed a shorter duration of green leaf area with less effective assimilatory capacity during capsule and seed growth. No differences in seed/capsule between the two cultivars have been observed.

\section{Thousand grains weight}

Seed index is one of the most important yield traits that has strong association with the grain yield plant $^{-1}$, and in selection criterion of crop varieties, this trait keeps major consideration. The data pertaining to 1000 grains weight of six linseed varieties are shown in (Table 3, Fig. 3) and its analysis of variance as (Table 1). The analysis of variance suggested that the differences in 1000 grains weight of different linseed varieties were statistically significant $(\mathrm{P}<0.05)$.It is evident from the results that the highest 1000 grains weight $(6.60 \mathrm{~g})$ was recorded in linseed variety Pr75 , followed by varieties Pr-17 and Pr-102 with $5.65 \mathrm{~g}$ and $5.65 \mathrm{~g}$ average 1000 grains weight, respectively against 5.57 g 1000 
grains weight in commercial variety Ilsi-90 (check). Similar findings were also reported that identifying the genotypes which have high further transfer ability in environmental condition especially in grain filling stage provides the possibility to increase yield of grains without any increase in the amount of consumed water [13].

Table 3. Mean values of capsules per plant, oil content, branches per plant, 1000 grains weight and seed index

\begin{tabular}{|c|c|c|c|c|c|}
\hline Varieties & $\begin{array}{c}\text { Capsules per } \\
\text { plant }\end{array}$ & $\begin{array}{c}\text { Oil } \\
\text { content }\end{array}$ & $\begin{array}{c}\text { Branches per } \\
\text { plant }\end{array}$ & $\begin{array}{c}\text { 1000 grain } \\
\text { weight }\end{array}$ & $\begin{array}{c}\text { Seed } \\
\text { index }\end{array}$ \\
\hline Pr-83 & 104.67 & 33.16 & 4.56 & 5.4 & 1021.55 \\
\hline Pr-84 & 104.33 & 33.88 & 4.48 & 5.38 & 1018.29 \\
\hline Pr-102 & 109.67 & 36.45 & 4.71 & 5.65 & 1037 \\
\hline Pr-17 & 109.67 & 37.19 & 4.47 & 5.65 & 1070.35 \\
\hline Pr-75 & 128 & 39.6 & 5.49 & 6.6 & 1282.48 \\
\hline Ilsi-90 & 108 & 35.74 & 4.62 & 5.57 & 1054.08 \\
\hline
\end{tabular}

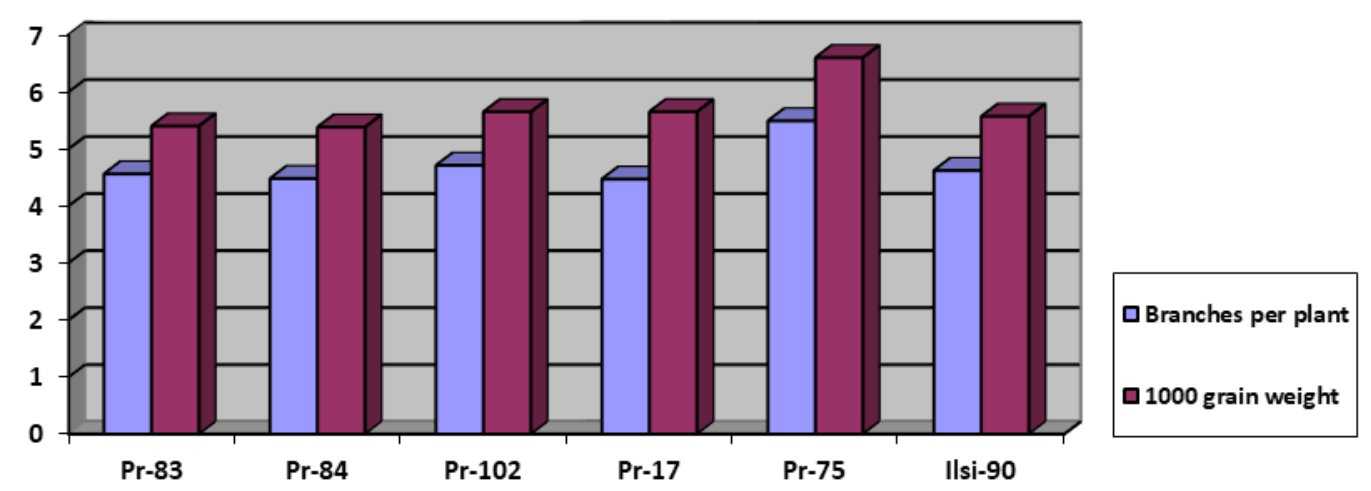

Figure3. Comparative mean performance of Branches per plant and 1000 grains weight

\section{Oil content $(\%)$}

Oil content is the most important trait in oilseeds such as linseed and even a crop variety produces higher seed yields, but oil content is not up to the criterion, such variety will not be useful. The results in regards to oil content of six linseed varieties are presented in (Table 3, Fig. 1) and its analysis of variance as (Table 1). The analysis of variance indicated that the differences in oil content in various linseed varieties were statistically significant $(\mathrm{P}<0.05)$. It is apparent from the results (Table 3) that the highest oil content $(39.60 \%)$ was determined in linseed variety Pr-75, followed by varieties Pr-17 and Pr102 with $37.19 \%$ and $36.45 \%$ oil content, respectively on average against $35.74 \%$ oil content in commercial variety Ilsi-90 (check). Similar results are comparable to those reported by [14].

Seed yield $\left(\mathrm{kg} \mathrm{ha}^{-1}\right)$

Yield is a measurement of the amount of a crop grain or seed that was harvested from per unit area of land and the yield is associated with a number of its components. The data regarding seed yield $\mathrm{ha}^{-1}$ of six linseed varieties are given in (Table 3, Fig. 2) and its analysis of variance as (Table 1). The analysis of variance demonstrated that the differences in seed yield $\mathrm{kg} \mathrm{ha}^{-1}$ of different linseed varieties were statistically significant $(\mathrm{P}<0.05)$.It is evident from the results that the highest seed yield of $1282.48 \mathrm{~kg} \mathrm{ha}^{-1}$ was produced by linseed variety $\operatorname{Pr}-75$, followed by varieties Pr-17 and Ilsi-90 (check) with average seed of $1070.35 \mathrm{~kg}$ and $1054.08 \mathrm{~kg}$ 
$\mathrm{ha}^{-1}$, respectively. Hence, on the basis of seed yield $\mathrm{kg} \mathrm{ha}^{-1}$, linseed variety $\operatorname{Pr}-75$ and Pr-102 could be the promising varieties for achieving higher linseed yields. Accompanied by high temperatures. Similarly, in the experiments by [15].

\section{Conclusion}

This study underlined the possibility to obtain, in the tested environment, an acceptable level of seed yields from linseed as spring crop, pointing out the different behaviour of the two varieties in terms of cycle length and yield components. However, the description of crop development, from emergence to seed maturity, timing and duration of each phenological phase, together with the corresponding growing degree days, accumulated rainfall and mean temperatures registered for each stage, are Pr-75 and Pr-17 could be promising for general cultivation under climate conditions of Tandojam.

\section{Authors' contributions}

Conceived and designed the experiments: MA Sahito, AH Sial \& FM Baloch, Performed the experiments: MA Sahito, AH Sial \& KR Kalwar, Analyzed the data: AL Siyal, Contributed materials/ analysis/ tools: MA Sahito \& FM Baloch, Wrote the paper: AL Siyal.

\section{References}

1. Ancuța P \& Sonia A (2020). Oil presscakes and meals valorization through circular economy approaches: A review. Appl Sci 10: 7432.

2. Ceh B, Straus S, Hladnik A \& Kusar A (2020). Impact of Linseed Variety, Location and Production Year on Seed Yield, Oil Content and Its Composition. Agron 10(11): 1770.

3. Chaudhary M, Rahul V \& Singh MP (2016). Chauhan. Study on genetic divergence in linseed (Linum usitatissimum L.) germplasm based on morphological and quality traits. Suppl on Gene and Plant Breeding 11: 953957.

4. Dabalo DY, Singh CS \& Weyessa B (2020). Genetic Variability and
Association of Characters in Linseed (Linum usitatissimum L.) Plant Grown in Central Ethiopia Region. Saudi J Biol Sci 27: 2192-2206.

5. Li X, Li J, Dong S, Li Y, Wei L, Zhao C, Li J, Liu X \& Wang Y (2019). Effects of germination on tocopherol, secoisolarlciresinoldi glucoside, cyanogenic glycosides and antioxidant activities in flaxseed (Linum usitatissimum L.). Inter $J \quad$ Food SciTechnol 54: 2346-2354.

6. Siyal AL, Ali GC, Nasiruddin S, Tahira J, Fozia KS, Jay KS \& Muhammad SC (2021). Screening of wheat genotypes for morphological, physiological and phonological traits under climatic conditions. Euro $J$ of Biol and Biotechnol 2(2): 78-91.

7. Mannucci A, Castagna A, Santin M, Serra A, Mele M \& Ranieri A (2019). Quality of flaxseed oil cake under different storage conditions. LWT 104: 84-90.

8. Piragine E, Flori L, Di L, Cesare M, Ghelardini C, Pagnotta E, Matteo R, Lazzeri L, Martelli A, Miragliotta V \& Pirone A (2020). Eruca sativa Mill. Seed extract promotes anti-obesity and hypoglycemic effects in mice fed with a high-fat diet. Phytother Res 1-8.

9. Rahman MJ, Costa de Camargo A \& Shahidi F (2018). Phenolic profiles and antioxidant activity of defatted camelina and Sophia seeds. Food Chem 240: 917-925.

10. Sanmartin C, Taglieri I, Venturi F, Macaluso M, Zinnai A, Tavarini S, Botto A, Serra A, Conte G \& Flamini G (2020). Flaxseed cake as a tool for the improvement of nutraceutical and sensorial features of sourdough bread. Foods 9: 204.

11. Siyal AL, Fozia KS \& Tahira J (2020). Yield from genetic variability of bread wheat (Triticum aestivum L.) genotypes under water stress condition: A case study of Tandojam, Sindh. Pure and Appl Biol 10(3): 841-860. 
12. Siyal AL (2017). Effect of bio fertilizer in addition with phosphorus on the growth of maize (Zea mayz L.). Inter J of Adv Res 5(12): 527-532.

13. Tavarini S, Castagns A, Conte G, L Foschi, Sanmartin C, Incrocci L, Ranieri A, Serra A \& Angelini LG (2019). Evaluation of Chemical Composition of Two Linseed Varieties as Sources of Health-Beneficial Substances. Mol 24(20): 3729.
14. Thakur R, Paul S, Thakur G, Kumar A \& Dogra R (2021). Assessment of genetic diversity among linseed (Linum usitatissimum L.) germplasm based on morphological traits. $J$ of Pharma and Phytochem 9(6): 1785-1790.

15. Zhang X, Lei L, Lai J, Zhao H \& Song W (2018). Effects of drought stress and water recovery on physiological responses and gene expression in maize seedlings. BMC Plant Biol 18: 68. 